THE COMMONS IN AN AGE OF UNCERTAINTY 
This page intentionally left blank 


\section{The Commons in an Age of Uncertainty}

\section{Decolonizing Nature, Economy, and Society}

FRANKLIN OBENG-ODOOM 
(C) University of Toronto Press 2021

Toronto Buffalo London

utorontopress.com

Printed in the U.S.A.

ISBN 978-1-4875-0176-1 (cloth)

ISBN 978-1-4875-1390-0 (PDF)

ISBN 978-1-4875-3761-6 (EPUB)

\section{Library and Archives Canada Cataloguing in Publication}

Title: The commons in an age of uncertainty : decolonizing nature, economy, and society / Franklin Obeng-Odoom.

Names: Obeng-Odoom, Franklin, author.

Description: Includes bibliographical references and index.

Identifiers: Canadiana (print) 20200212427 | Canadiana (ebook)

2020021246X | ISBN 9781487501761 (hardcover) |

ISBN 9781487513900 (PDF) | ISBN 9781487537616 (EPUB)

Subjects: LCSH: Commons. | LCSH: Public lands. | LCSH: Right

of property. | LCSH: Decolonization.

Classification: LCC HD1286 .O24 2020 | DDC 333.2 - dc23

University of Toronto Press acknowledges the financial assistance to its publishing program of the Canada Council for the Arts and the Ontario Arts

Council, an agency of the Government of Ontario.

Canada Council Conseil des Arts for the Arts du Canada
ONTARIO ARTS COUNCIL

CONSEIL DES ARTS DE L'ONTARIO

an Ontario government agency

un organisme du gouvernement de l'Ontario 
Dedicated to the Original Land Economists whose vision, if revisited and revamped, would generate the much-needed certainty for our age, a possible alternative, on which visionaries like Anne Haila (1953-2019) worked until she returned to the land. 
This page intentionally left blank 